\title{
THE ECOMUSEUM IN THEORY AND PRACTICE THE FIRST CHINESE ECOMUSEUM ESTABLISHED
}

\author{
An Laishun
}

John Aage Gjestrum

The first Chinese ecomuseum was opened on October 31st 1998. This was a result of four years of co-operation between Chinese and Norwegian museum professionals, state authorities on various levels and the people of a local ethnic minority in Guizhou province. At the signing of the official project agreement in 1997 the Chinese head of state Jiang Zemin and the Norwegian King Harald and Queen Sonja, were present. It is very rare for a museum project to attract such high level attention.

It is quite a distance from the palaces of Beijing where this event took place to the Soga community and the Qing Miao minority group, with a population of 4,000 living under the poorest conditions in a high mountain area in Guizhou province.

At the end of 5 years one may ask what the result is of the ecomuseum project in Guizhou. What has been a success, what has failed, what is specific to an ecomuseum in a Chinese context, - and finally, what are the future prospects for ecomuseums in China? Some of these questions will be answered in this text, and some will just be raised. This year (1999) the ecomuseum project is entering its second stage, - with the planning of three more ecomuseums, all of them linked to minority peoples in Guizhou province, a part of China which has only been opened to outsiders in recent years.

\section{THE CURRENT SITUATION \\ OF CHINESE MUSEUMS}

As background material some facts about the museum situation in China will be provided. During the two decades since 1978 when China started on the road of reform opening up to the outside world, Chinese museums have increased both in number and type. 
66 Today, China has about 1900 museums. In the Chinese museum management system, the majority of museums are so-called «cultural system» museums. These museums are mainly supported and supervised by cultural heritage authorities on different levels. According to statistics, in 1980 there were 365 museums within this system with 6,12 million museum objects. By 1998 the number had reached 1331, with more than 10 million objects. These museums make up about $2 / 3$ of the total number of museums at the moment.

Outside this system, a diversified museum typology has gradually been developed over the last ten years. At least 500 museums were respectively founded and run by other authorities and universities, industrial companies, and even by private individuals. As an example at least two new museums will be opened in Beijing this autumn. One is a private museum - «The Red Wood Furniture Museum» - which recently opened and another is a company museum of bronze art which will open at the end of September. There are now 9 private museums, accounting for almost $10 \%$ of the 102 museums in Beijing, the capital city of China.

The majority of the existing museums hold archaeology, art and fine art collections, and treasures from the emperors' dynasties as a result of the long history and richness of archaeological excavations. Other types of museums, especially folklife museums focussing on traditions of everyday culture, are still rare.

Chinese museums have grown and developed on Chinese soil, they are endowed with Chinese characteristics determined by both the cultural background and the politics and philosophy of the nation. However, since museums represent worldwide cultural phenomena, Chinese museums are also a part of the world's museums and thus share common characteristics. It is very natural for Chinese museum professionals to start a process of internationalization in the 1980s. One milestone was China's participation in the International Council of Museums (ICOM) in 1983. Since then, regular international exchanges and cooperation programmes have gradually been developed.

\section{MODERNIZATION AND SOCIAL TRANSITION - A CHALLENGE TO MINORITY CULTURAL HERITAGE AND MINORITY TRADITIONS}

In the process of modernization, China has has undergone a variety of social and economic transitions: from an agricultural to an industrial society, from an industrial to an information society, from a stagnant to a developing society, and from a planned to a market economy. All these transitions have greatly influenced our cultural patterns, and particularly challenge the minority cultures in the rural areas which have just opened up to the outside world.

One of the crucial issues concerning minority cultures is that in areas which were opened at an early stage, some parts of their unique cultures have been gradually buried as a result of economic development and the tourist industry. Problems - such as what can be learnt from previous failures, and what people should do in the other newly opened minority areas - have attracted great attention. Chinese professionals in 
museums and cultural heritage agencies have also realized that there is an urgent need to find some constructive theoretical concepts and successful practices presented by other national and international experiences, in order to provide local minority communities with the tools needed to handle the balance between the protection of their cultural identity and rational social and economic development.

\section{THE INITIATIVE OF THE PROJECT ECOMUSEUMS IN GUIZHOU}

In September 1994, the International Committee for Museology of ICOM (ICOFOM) held its annual conference in Beijing. During the meeting some Chinese museologists discussed the basic ideas of the ecomuseum concept with a museologist from France (André Desvallées), where the ecomuseum was initiated in 1971, and with a museologist from Norway (John Aage Gjestrum) where the ecomuseum concept has been successfully developed and practised. The Chinese museologists took a very great interest in experiences from the Norwegian ecomuseums.

As a result of this constructive discussion, the Chinese Society of Museums (CMS), a nongovernmental organization of museum professionals in China, launched a study into the possibility of establishing ecomuseums in China. It was suggested that Guizhou province, which was opened in the mid-80s, rich in minorities and minority cultures and eager for economic development, should serve as the test case. Soon afterwards a project team was established conducted by CSM. John Aage Gjestrum was invited to join as a member and as scientific adviser. NORAD and related Norwegian authorities have supported this study.

Guizhou is a Chinese province with 32 million people, of whom about $65 \%$ are Han and the rest a mixture of ethnic minorities. Mountains and plateaus make up $87 \%$ of Guizhou's topography, which has an average altitude of $1000 \mathrm{~m}$ above sea level. It is one of the richest provinces in terms of unique minority cultures, and one of poorest provinces in its economy. Statistics show that in 1997, the total provincial income was only about $1 / 10$ of that in Shanghai, China's biggest industrial city. The protection of a minority cultural heritage faces serious challenges in the eager desire for economic development and the urgent needs to improve people's living conditions.

In April 1995, the project team investigated 12 villages in Guizhou where Miao, Buyi, Dong and Han national groups live in compact communities. The project team combined the basic concept of the ecomuseum with the actual conditions of Guizhou, and suggested setting up China's first ecomuseum in Soga, a unique Miao community. Following this, three other ecomuseums representing different nationalities and minority cultures would be planned in Guizhou. The Chinese government at both central and provincial levels approved the project on the principles proposed in a Study Report by the project team. An application for further Norwegian scientific and financial assistance was also made to NORAD in the same year. With the approval of NORAD, the project Ecomuseums in Guizhou Province was formalized in 1995 as a China - Norway cooperation project. At 
68 the official signing of the project agreement on 23 October 1997, the Chinese President Jiang Zemin and the Norwegian King Harald and Queen Sonja were present.

\section{AN INTRODUCTION TO THE ECOMUSEUM CONCEPT}

Sunce the concept of the ecomuseum was introduced in France in 1971 it has become an important part of the museum scene in many countries in Europe, LatinAmerica and Canada.

As is well known, the main theoretical starting point of the ecomuseum is that people should not be separated from their cultural heritage but that they should have the opportunity to create their future based on it. From this position all practical action is developed making the ecomuseum very different from the traditional museum. The traditional museum as we know it is needed for scientific and many other reasons and the ecomuseum is not in any way a substitute for other museums. Instead it widens the museum concept to include new social functions.

While the traditional museum is based on moving the heritage into a museum building - very often far away from the original owner of this heritage (and its environment) - the ecomuseum is based on the idea that the heritage within a specific community should be preserved in situ. The territory of the community and the space of the museum accordingly will be the same.

The heritage: landscape, buildings, movable objects, traditions - the content of the culture in this specific community is given value by the ecomuseum - and at the same time the ecomuseum will be an instrument for its safeguarding and future preservation.

Instead of seeing the museum as very clearly defined - with collections and museum buildings - the ecomuseum must be seen as a long-term working method in the preservation and understanding of the specific material and immaterial culture of a human group.

This increased understanding will strengthen cultural identity. It is based on participation and controlled by the group itself, guided by museological and scientific experts and supported financially by the authorities.

Today, at the end of the 20th century and the beginning of the 21st century, the paradigm of ecological limitations is important to mankind - and the eco- in the name ecomuseum is the Greek word for household - housekeeping.

Some basic keywords in the ecomuseum concept are:

- territory

- heritage

- population

- memory

- popular education

- participation

- ecology

- identity

The ecomuseum as a working model in the field of heritage and cultural values in a community will strengthen the cultural identity of the group. This can be a major contribution to the future survival of the culture. The ecomuseum therefore has a very clear social function. It will also serve as a link between the past, the present and the future. 


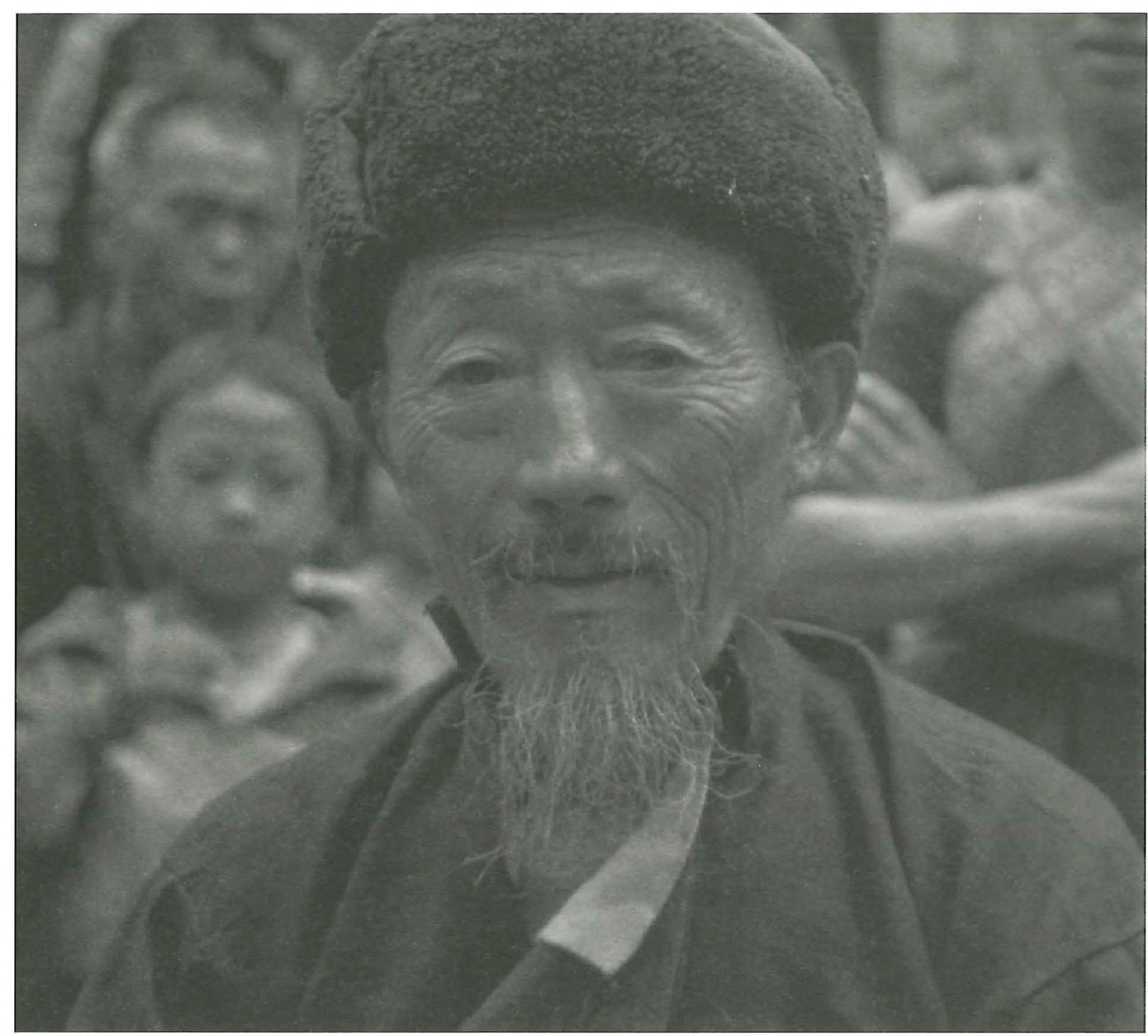

Xiong Shaoan (75) is both elder and shaman in the village AnZhu - one of the 12 Qing Miao villages in Soga, Guizhou province, China. Photo: John Aage Gjestrum/Soga ecomuseum.

The 25 years of ecomuseum experience has provided many examples of how these principal ideas have been adapted to practical situations.

In theory the ecomuseum considers all cultural and natural heritage within its specific territory as part of the museum. However, this is a theoretical position: everything is a potential part of the documentation of the history and present culture of the group.

In practice the ecomuseums have been organized in a variety of ways. One of the most important parts however is a documentation centre. This is simultaneously:
1. A data bank for the documentation of the specific culture, consisting of tape recordings of oral history (language and traditions), photographs, written sources, specific valuable objects, inventories with registration of objects, buildings and other parts of the heritage in the territory etc.: the data bank represents a rich source of knowledge that should be safely preserved and studied both by the population itself and by visiting researchers.

2. A visitors' centre giving an introduction (a small exhibition) to the specific culture and people being visited, how they as 
visitors (guests) should behave, and what they can see and experience during their visit. This can also be done using audio-visual media.

3. Working facilities and technical equipment for the museum staff and volunteers working on documentation, research and interpretation.

4. Normally there are also some areas for social functions such as a small restaurant and conference/activity rooms.

The other main part of the ecomuseum structure is what in France is called the antennae of the ecomuseum. That is those parts of the heritage preserved in situ chosen to be accessible to visitors, and given a specific interpretation. Each one of these visiting points is normally very small and covers only one or a few aspects of the heritage. However, because of the very authenticity of these selected sites (points), - the total experience of the visitor will be very wide.

In the world today there are more than 300 ecomuseums, in Southern Europe (70; France, Spain, Portugal), Scandinavia (50; Norway, Sweden, Denmark), Latin America (90; Brazil, Mexico), Northern America (20; USA, Canada). There are also ecomuseums in other countries throughout the world.

In every country and in every museum project the ecomuseum is realized differently - based on the specific cultural situation and personnel and economic resources. Some projects are mostly directed towards the needs of the local population, others more towards outside visitors.

In all cases the work on preservation of the heritage and the museum work are integrated and seen as a whole, strongly emphasizing the participation of the local population in the work and giving weight to the social function of the museum.

This makes the ecomuseum different from other types of museum, while supplementing the work done by them. The bigger museums on national, provincial and regional level will therefore find it very useful to co-operate with the smaller ecomuseums situated at the grass-roots level. Some results of the ecomuseum work may be:

- to increase the importance of the concept of heritage;

- to increase the self-confidence of different communities;

- to increase the possibility of an ecologically responsible/sustainable future;

- to increase social responsibility;

- to increase scientific long-term resources;

- to increase the museum's role in popular education;

- to increase knowledge about other cultural groups, resulting in tolerance, respect and mutual trust.

\section{THE SOGA ECOMUSEUM - THE FIRST CHINESE ECOMUSEUM}

Soga Ecomuseum, which is the first ecomuseum in China, represents a unique ehtnic group of the Miao nationality.

According to statistics the total Miao population in China was 7,390,835 in 1990. It is the fourth biggest minority nationality of China. About half the Miao population lives in Guizhou. Miao is a nationality with 5,000 years of history. Originally this nationality lived along the lower reaches of the Yangtze and Yellow 


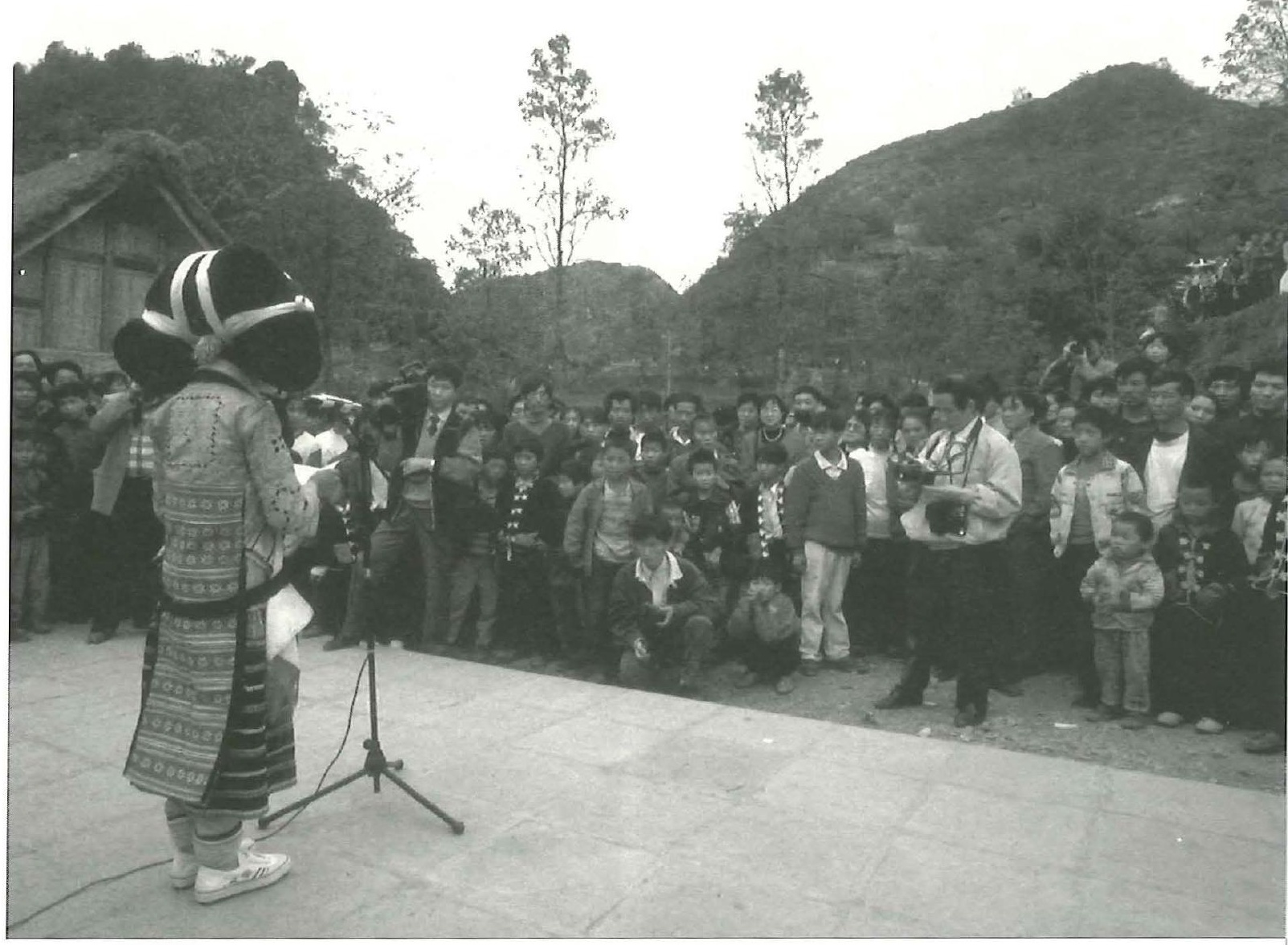

From the opening ceremony of the Soga ecomuseum documentation centre in LongGa village October 31st 1998. Xiong Huayan is speaking on behalf of the Qing Miao people.

Photo: John Aage Gjestrum/Soga ecomuseum.

Rivers. Endless wars forced them to move from there to the south and southwest part of China as well as Southern Asian countries. By the time of the Qing dynasty (17th century) the Miao had undergone five great migrations. Some scholars have described the history of the Miao as «a history of fighting, and a history of migration».

Deep in the mountains in the central part of Guizhou, is Soga community, in the Liuzhi District (a small part of it belongs administratively to the Zhijin district), here lives the rarest and the smallest branch of the Miao with a specific cultural identity all their own. In 1996, this ethnic group had 4,069 people and 996 families distributed in 12 villages. Living in the remote high mountains from 1,400 to $2,000 \mathrm{~m}$ above sea level all the year round, the people here have had no continuous contact with the outside world until late in the 1980s when a new road was built. The community has an old and unique Miao culture, symbolized by a head ornament made of long ox horns. Although the local people usually call this group of people "Longhorn Miao", the group itself prefers and more often uses its own "official» name "Qing Miao» (the literal meaning being 'the Miao people who live in high mountains with big trees and dense grass'). 

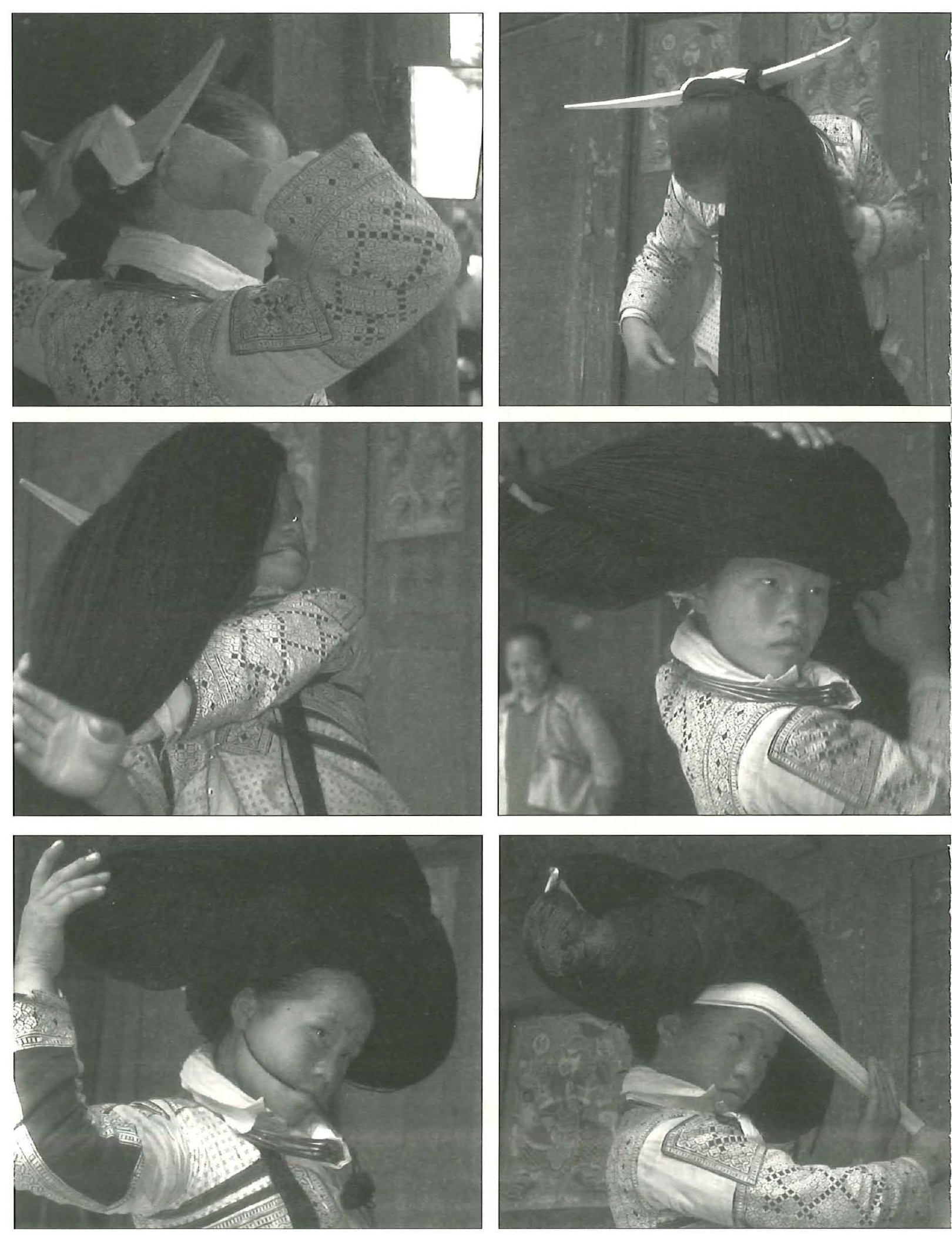


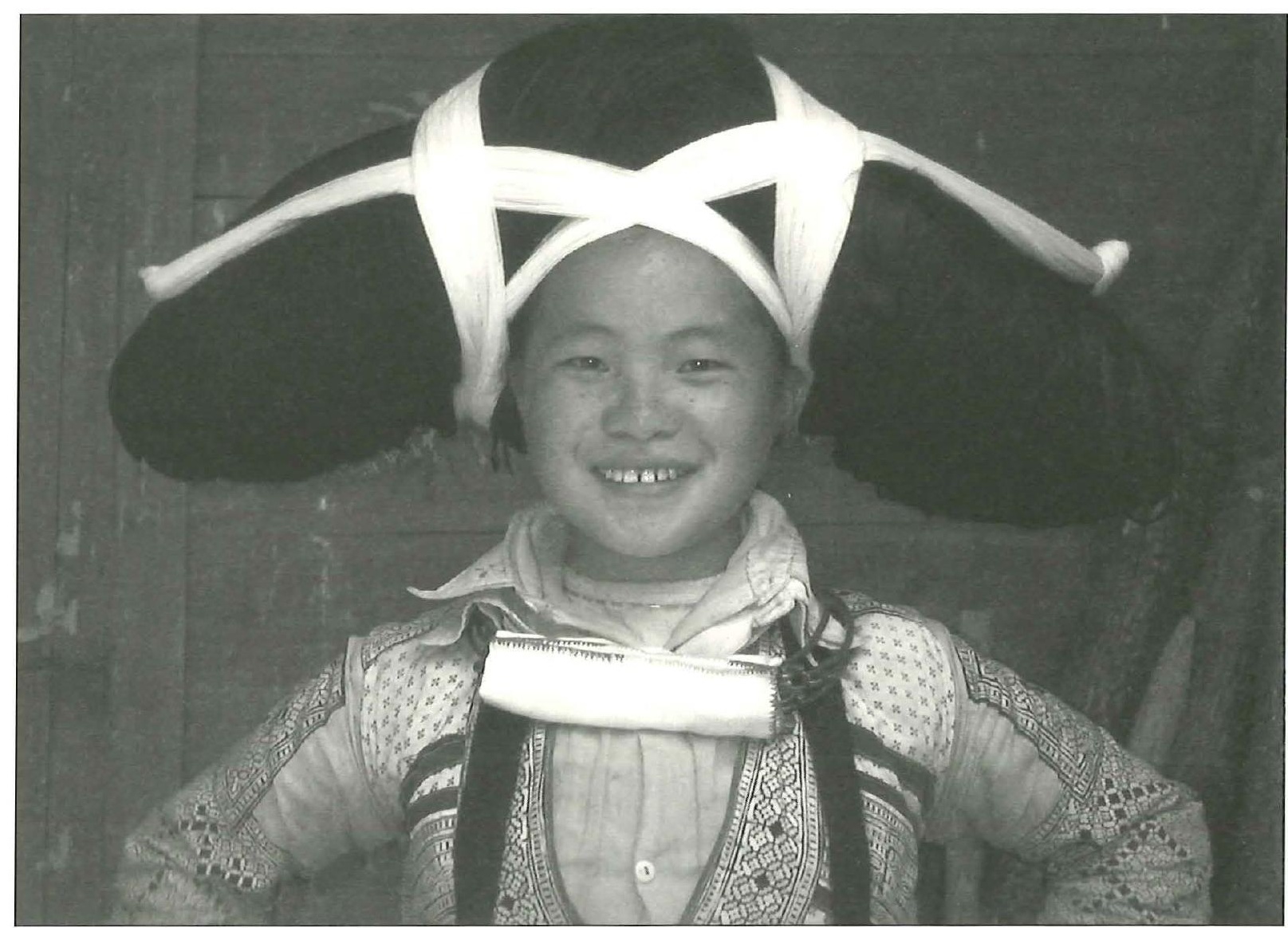

The wooden head ornament symbolizes the long ox horn. It is traditionally used by the women of the Qing Miao people. At festivals, weddings and on other special occasions a big hair is added as decoration. The pictures show how this head decoration is made.

Photo: John Aage Gjestrum/Soga ecomuseum.

\section{Natural Landscape}

Due to the geographic conditions, there are almost no or only very difficult roads. The villages are situated 2 to 15 kilometres from the main roads, depending on their specific locations. Obviously, the Qing Miao people chose these particular geographical conditions in which to site their villages for military reasons, since these places are easy to defend and hard to attack.

\section{History}

The local historical records and Qing Miao's oral history passed down by the elders indicate that this branch of the
Miao might have come here and settled in the first part of the 17th century, escaping from the harsh wars fought between a local minority bureaucrat and the emperor's forces.

\section{Economy}

Most Qing Miao villages are still at the stage of a natural economy - men cultivate the land and women weave gunny cloth. Due to the high mountains and shortage of water the residents here have to reclaim arid wasteland to grow and harvest a small amount of corn and potatoes. Poultry, cattle, pigs and ducks are also raised. 
An Laishun \& John Aage Gjestrum

74 The houses have straw roofs and walls of wood and clay, or are made of mud. Building materials of wood were easily available in earlier times, but are now expensive. Each family lives in a threeroom house. One room has a stove which is kept alight all the year round. The stove is used for cooking, heating and boiling wax.

\section{Culture}

The Qing Miao community preserves an amazing treasure of music and dances, as well as fascinating customs, dress and handicrafts.

Unique music and dances: Music from the long three-hole xiao (a vertical bamboo flute) is low and deep as if telling people about the sufferings caused by wars; the lively sound of the bamboo sheng (a reed pipe wind instrument) and bamboo leaves is not as loud and sonorous as the tunes of other Miao groups.

Wax printing and embroidery: With natural plant dye, the wax printing here is of high quality. Every household has its own dye vats. A girl starts to learn embroidery at a very young age. An embroidered product is an embodiment of the intelligence and wisdom of a girl.

\section{Religion}

The Miao nationality believes in polytheism. Qing Miao people worship the God of the Mountain, so once a year they hold a ceremony to pay their respect to this god. A shaman is the religious and spiritual leader in the village. He tells fortunes, cures diseases, presides over memorial ceremonies and exorcises ghosts for the residents. The shaman enjoys a high reputation.
Social Life

Each of the Qing Miao villages is mainly governed by three leaders called the Chief, the Elder and the Shaman. The Chief is the administrative commander; the Elder is the moral master and the Shaman is the religious head. The three leaders are not elected by the residents but come to power naturally during the long course of their lives. They need not campaign for office or be nominated. The local government also appoints a man as the village director. But in most cases, the man nominated is the Chief, so the appointment is accepted easily by the residents. The difference is that the people do not call him director; they still consider him as the Chief.

\section{STARTING ACTIVITIES IN THE SOGA ECOMUSEUM PROJECT}

Adhering to the basic principles of the ecomuseum, the following work has been done as the first stage:

Establishment of the documentation centre of the Soga Ecomuseum in Longga Village, one of the representative villages in the community.

Longga village is situated in the centre of Soga community, and it is also one of the original villages of the Qing Miao people. Longga has 97 households and 490 inhabitants. More than 200 years ago, 5 families settled here. On October 31, 1998, the Soga ecomuseum was opened together with the Documentation Centre.

The functions of this documentation centre are to serve as:

- a data bank of the Qing Miao history and collective memory

- an interpretation centre with an intro- 


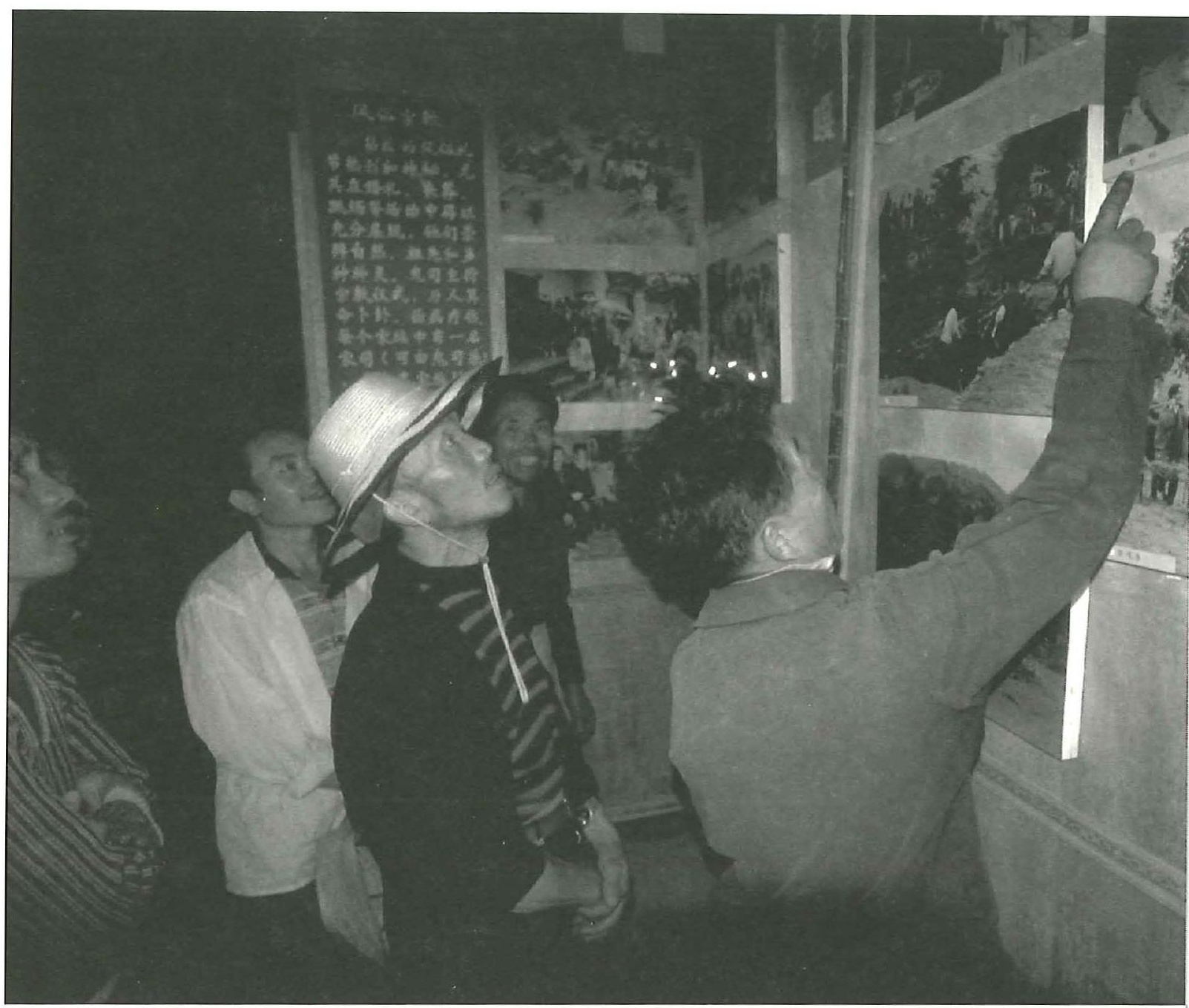

Village leaders from Soga visiting the exhibitions in the Soga ecomuseum documentation centre.

Photo: John Aage Gjestrum/Soga ecomuseum.

ductory exhibition

- a community centre where the local population can meet for social activities

- a cultural centre where the local population can celebrate their festivals.

The architecture of the documentation centre was designed jointly by an architect and the village people. Thus traditional features of village buildings can easily be recognized in this centre. The major part of the construction work was finished by village craftsmen using their traditional techniques.

One of the core issues of Soga Ecomuseum is to preserve and document the collective memory of the community through direct participation of the local population. The objectives for this part of the project are:

- to increase the importance of heritage in Soga community

- to increase the self-confidence of the Qing Miao people

- to increase the capacity for an ecologically responsible and sustainable future

- to increase long-term scientific resources.

This first stage is called Qing Miao Memory. The first training course in Qing Miao Memory was held at the documen- 
An Laishun \& John Aage Gjestrum

76 tation centre. The participants were seven young people from Longga village. The Norwegian and Chinese museologists conducted the training in both ecomuseology and museography. Like the other Miao groups, the Qing Miao have no written language of their own. Using their own language for the documentation work was now strongly encouraged. These young people are the first group to date to work with their collective memory by recording oral history and legends told in their own language. The first nine tapes were recorded and stored in the documentation centre. This work is being led by two Qing Miao women in Longga and 11 other villages.

Another core issue, the social and economic development of Soga community, is being considered in the first stage of ecomuseum practice.

Before the ecomuseum was established,

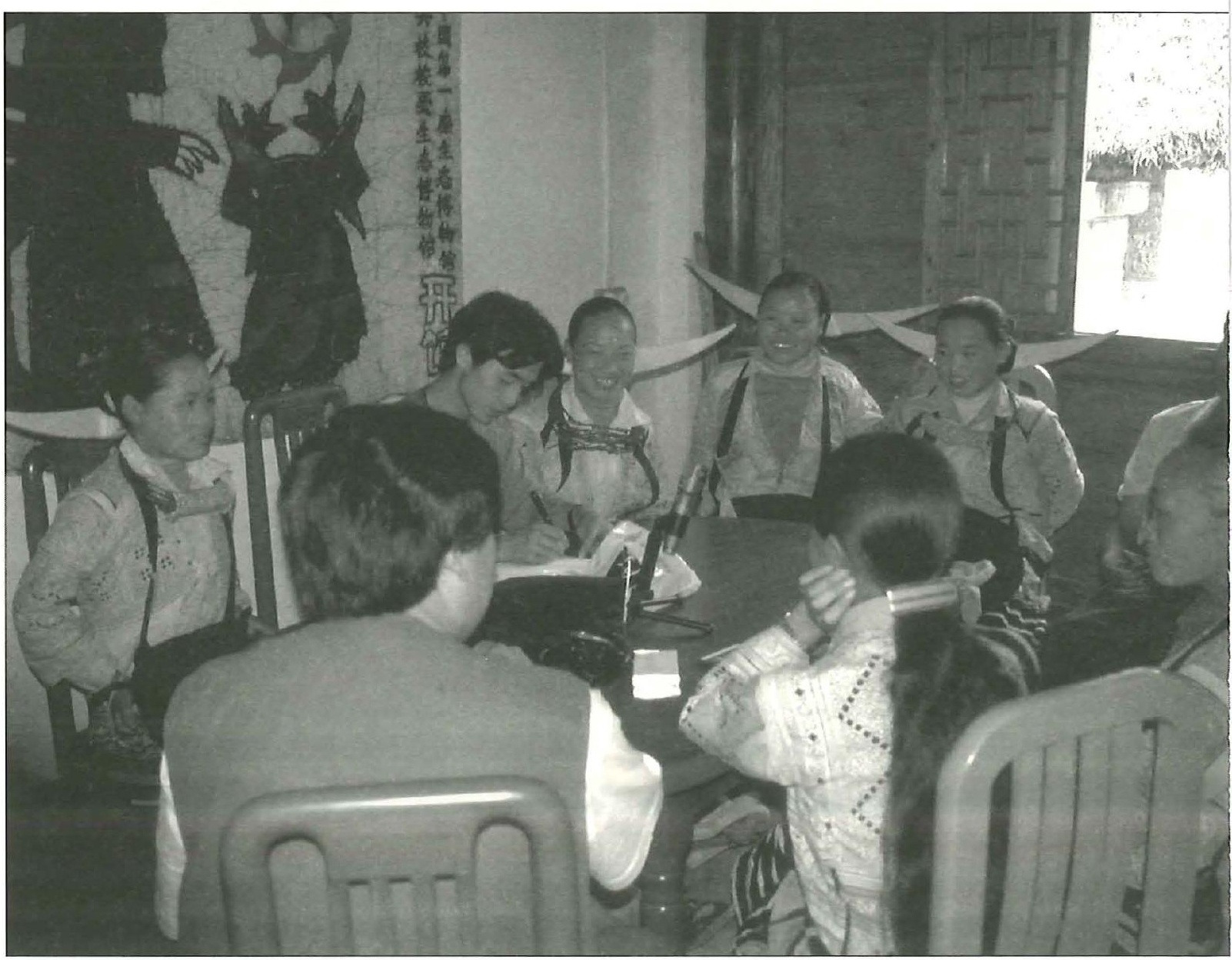




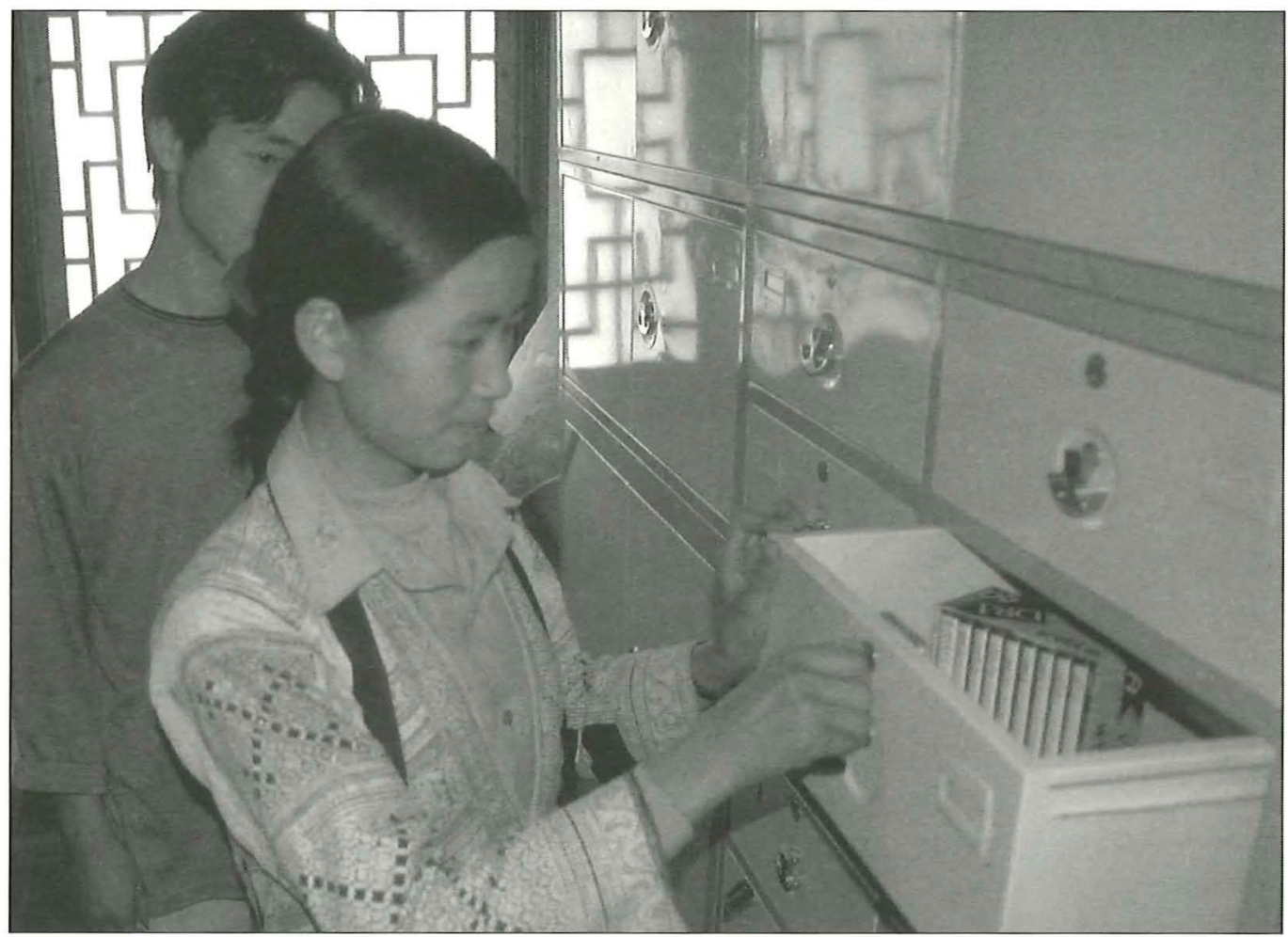

The first training course in the Qing Memory project took place in August 1999. Seven young people from LongGa village were trained in making oral history recordings in their own language. Above the first 9 tapes are being locked into the documentation centre by Luo Gang (22) and Xiong Huayan (21), who are in charge of the project. Photo: John Aage Gjestrum/Soga ecomuseum.

the school in Longga village was a cattle house, pupils had to study in the dark and with little space. The project partly supported the construction of a new school building in 1996. Now about 280 children from Qing Miao community can attend the Longga school. In Longga, the percentage of children going to school is $92 \%$, which is much higher than the average $30 \%$ to $40 \%$ in the other Qing Miao villages. In this school, two classes for girls were organized. Following the ideas of the ecomuseum, Longga villagers themselves have developed some specific courses for training in handicrafts for the girls at the school instead of them staying at home to learn. All the school courses are taught in both the Miao and Han languages.

Soga Ecomuseum also promoted the supply of electricity. As a result of the project, Longga and three other Qing Miao villages have had an electricity supply since 1996.

The construction of the documentation 


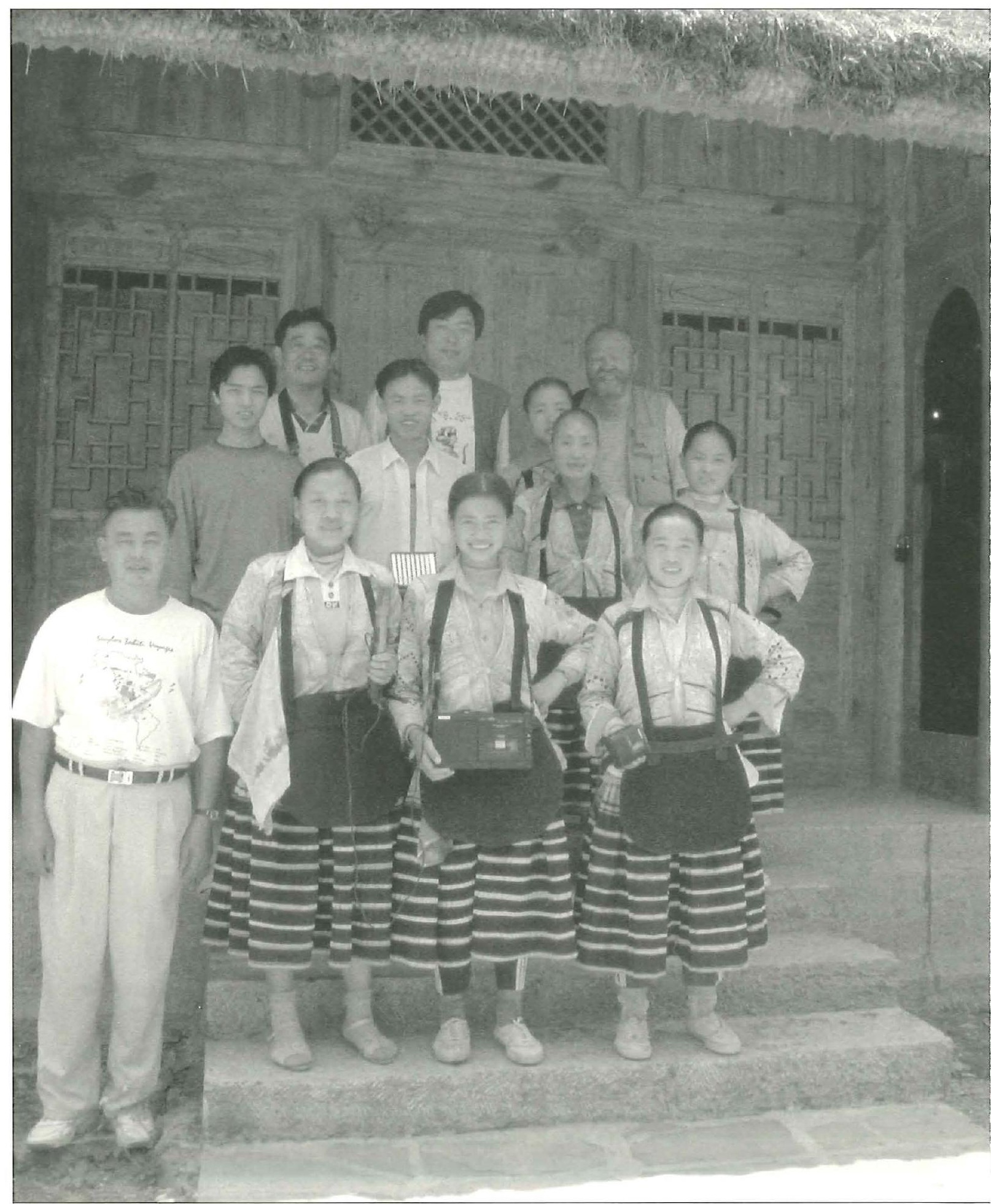

The first group of young people from a national minority group to be trained in an ecomuseum oral history project in China. Photo in front of the Soga ecomuseum documentation centre at the end of the training course August 8, 1999. Photo: Soga ecomuseum. 
centre created some job possibilities, quite a large number of Longga villagers benefited from this construction. Longga village has also increased its income by receiving visitors and by organizing performances even though this income is still very limited.

\section{EVALUATION OF THE FIRST STAGE}

An evaluation of the first stage of the project was carried out by the project team last November. A further investigation was made in August 1999 by the Chinese and Norwegian team members. Interviews were conducted with 18 village leaders from 11 of the 12 villages. Seven villages in total were visited for purposes of documentation and observation.

The interviews with the 18 village leaders revealed very clearly their opinions of the importance of Soga Ecomuseum. They were all aware of the ecomuseum, and were positive to the museum idea. The reasons given were:

- They considered the ecomuseum a tool to be used to protect their traditions and heritage.

- They considered the ecomuseum a tool for social and economic development.

- They considered the ecomuseum a community centre for the whole Qing Miao group. Until the establishment of the ecomuseum no such centre existed.

- The Qing Miao people on one hand want to protect their culture and traditions, but on the other they want social and economic development so that their quality of life can be improved. In the opinion of the community leaders the ecomuseum will support both objectives and contribute to a balance between them.

However, the Qing Miao people are facing some new problems in balancing protection and development.

Agricultural conditions in Soga community being very hard corn and potatoes are the main products in all the villages, and only a few of them can produce enough food for their needs. Infant mortality figures in some of the villages are as high as $10 \%$. This is very clearly linked to the great difficulties in supplying sufficient drinking water. A school attendance rate of only $30-40 \%$ of the children is normal.

The community has an urgent need to improve its quality of life. Meanwhile, the influence of the tourist industry has gradually made itself felt. Longga village started to receive visitors in 1991 . The development of the ecomuseum has led to a great deal of interest from the media and tourist companies. On the Internet, people can buy ticket direct to Longga from every corner of the world. It is not always easy for local people to handle the situation when a foreign tourist's expenses for one day are almost 10 times a villager's yearly income. All what they have is their cultural heritage. If their living conditions are not improved, if the tourists cannot behave in a proper way, if the real value of their cultural heritage is not fully recognized by the villagers, what will happen to the costumes and handicraft?

Some solutions must be found in the second stage of the project. 
An Laishun \& John Aage Gjestrum

\section{THE SECOND STAGE OF THE PROJECT}

The Chinese and Norwegian government support is substantial. A letter of intent regarding the second stage of the project was signed by a Chinese representative and the Minister of the Environment for Norway during her visit to China in March 1999. In its second stage, from 1999 to 2001, the project is supposed to include both the further development of the Soga Ecomuseum and the planning plus the first steps to establishing three more Chinese ecomuseums in Guizhou.

In the plan for the further development of Soga Ecomuseum, the priority has been given to the following points:

- Registration and documentation of 12 Qing Miao villages. More detailed documentation of Qing Miao culture in all aspects should be carried out. The results from this will form an important part of the documentation centre. The Qing Miao Memory project will be continued for the whole three years.

- An improvement in the water supply of

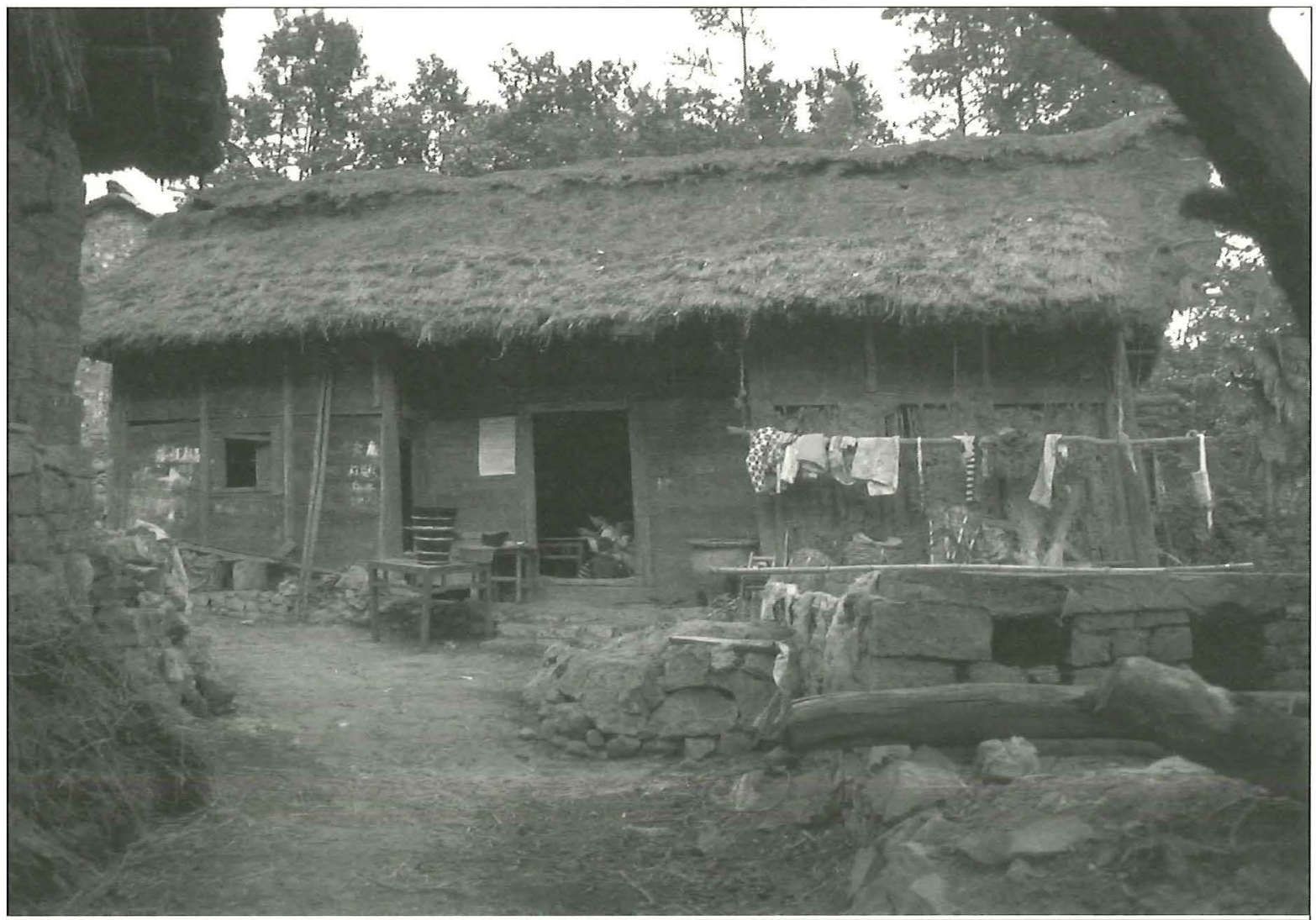




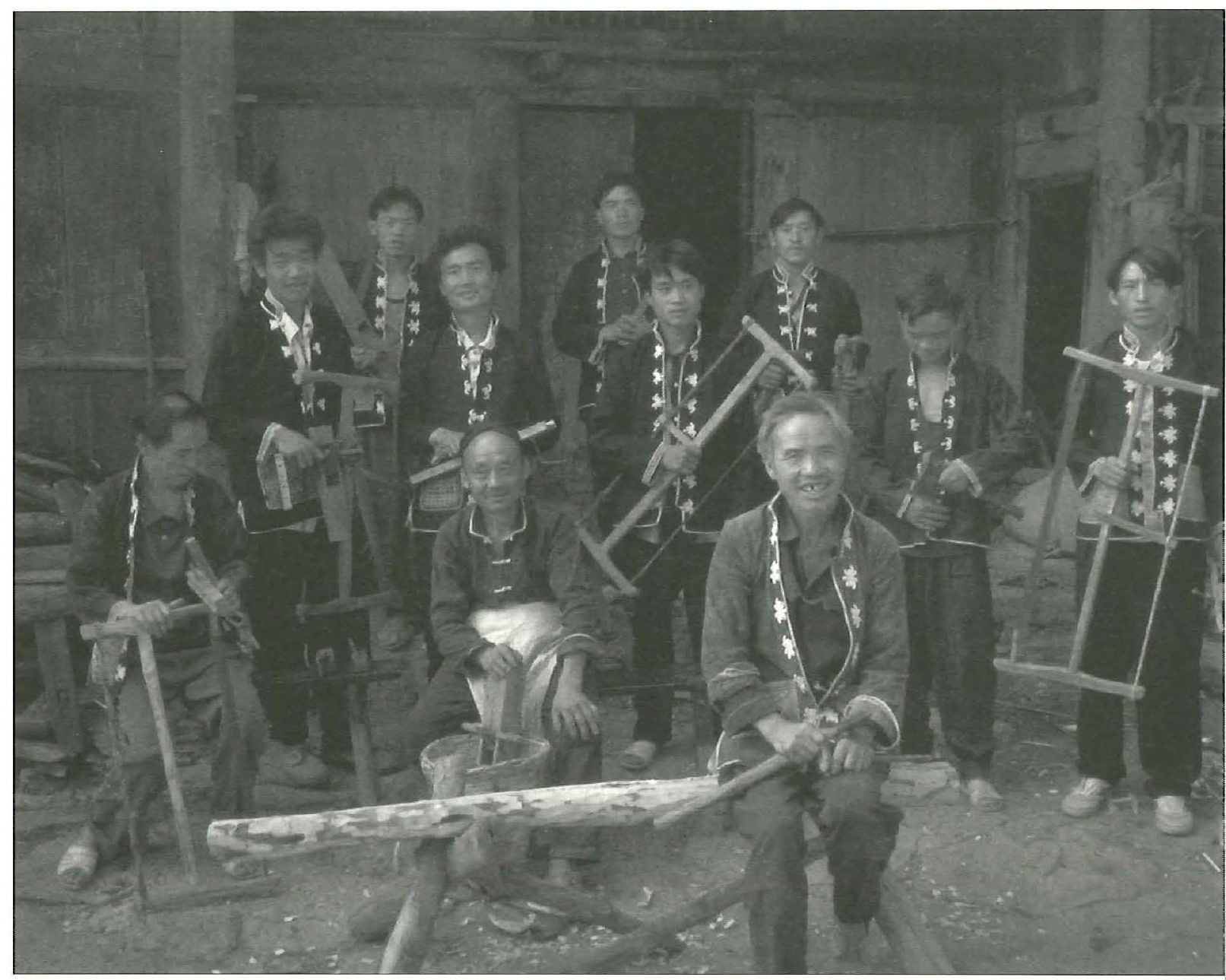

Houses in Soga were traditionally built in wood. In LongGa village 10 houses have been chosen for restoration, - one of them pictured on the left page. Above: Craftsmen from LongGa who participated in the construction of the ecomuseum, are now ready for the restoration work. In front: Xiong Shaoweio and Xiong Yuming, both 61 years old. Photo: John Aage Gjestrum/Soga ecomuseum.

Longga and three other villages. Improvements to the infrastructure of the community related to the social conditions are to be given very high priority. This is an important social issue linked with the ecomuseum as a cultural project.

- Preservation and restoration of architecture. In Longga village, 10 buildings have been chosen as the most valuable ones from a cultural heritage point of view. These buildings are up to 200 years old. All the buildings will continue to be used for their original functions, and the restoration work will be done using traditional techniques by the craftsmen from the village.
- Arts and craft development. There is a very clear need for quality products that can be offered to the tourists. Making traditional costumes with the specific and very important high quality wax painting is one of the possible crafts that can be introduced in an arts and crafts project.

- Controlled tourism using various methods. This is linked to the very clear intention of avoiding the negative influence of tourism that has occurred in the neighbouring province of Yunnan, where tourism has actually destroyed some extremely important parts of minority cultures. This possible 'pollution' as a result of tourism is very clear to the 
An Laishun \& John Aage Gjestrum

82 Guizhou authorities. One of the important problems is connected with drawing a line between what is a national minority heritage and what are arts and crafts. When there is no organized production and sale of high quality handicraft products, tourism exerts a strong pressure on people to sell the cultural treasures they have at their disposal. In Longga there were tourist visits several years before the ecomuseum came into being. The ecomuseum can therefore play an important part in securing high quality products, and in this way also help the population to generate necessary income. Very specific steps have al- ready been taken to establish separate village rules on how to handle these issues. At the same time the provincial government is preparing guidelines for the tourist authorities.

\section{THE NEXT THREE CHINESE ECOMUSEUMS}

The planning of and the first steps towards establishing the next three Chinese ecomuseums in Guizhou is linked to three communities that have been chosen from a scientific and heritage point of view: Zhenshan Village in the Huaxi District of Guiyang city; Longli old town

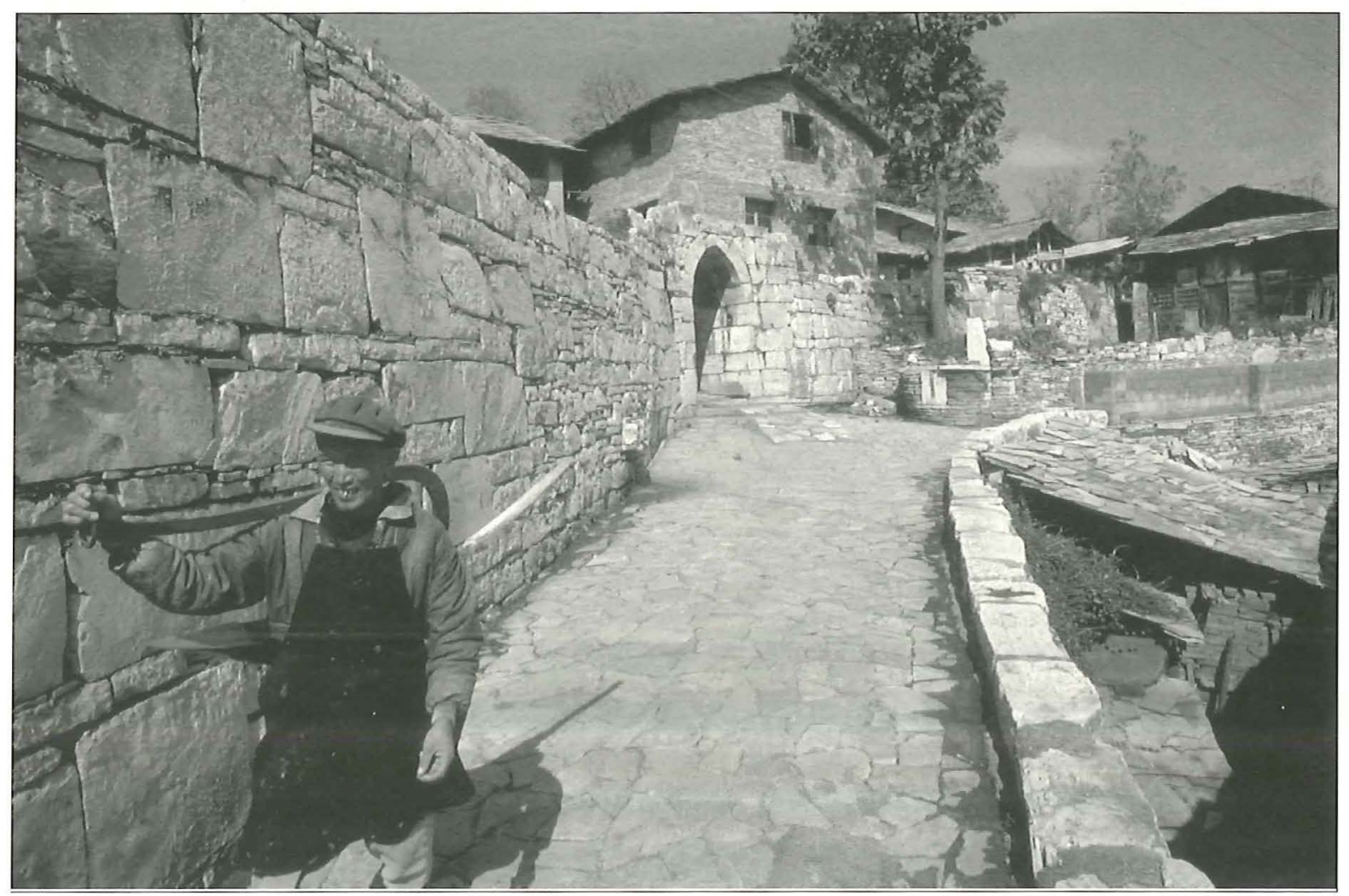




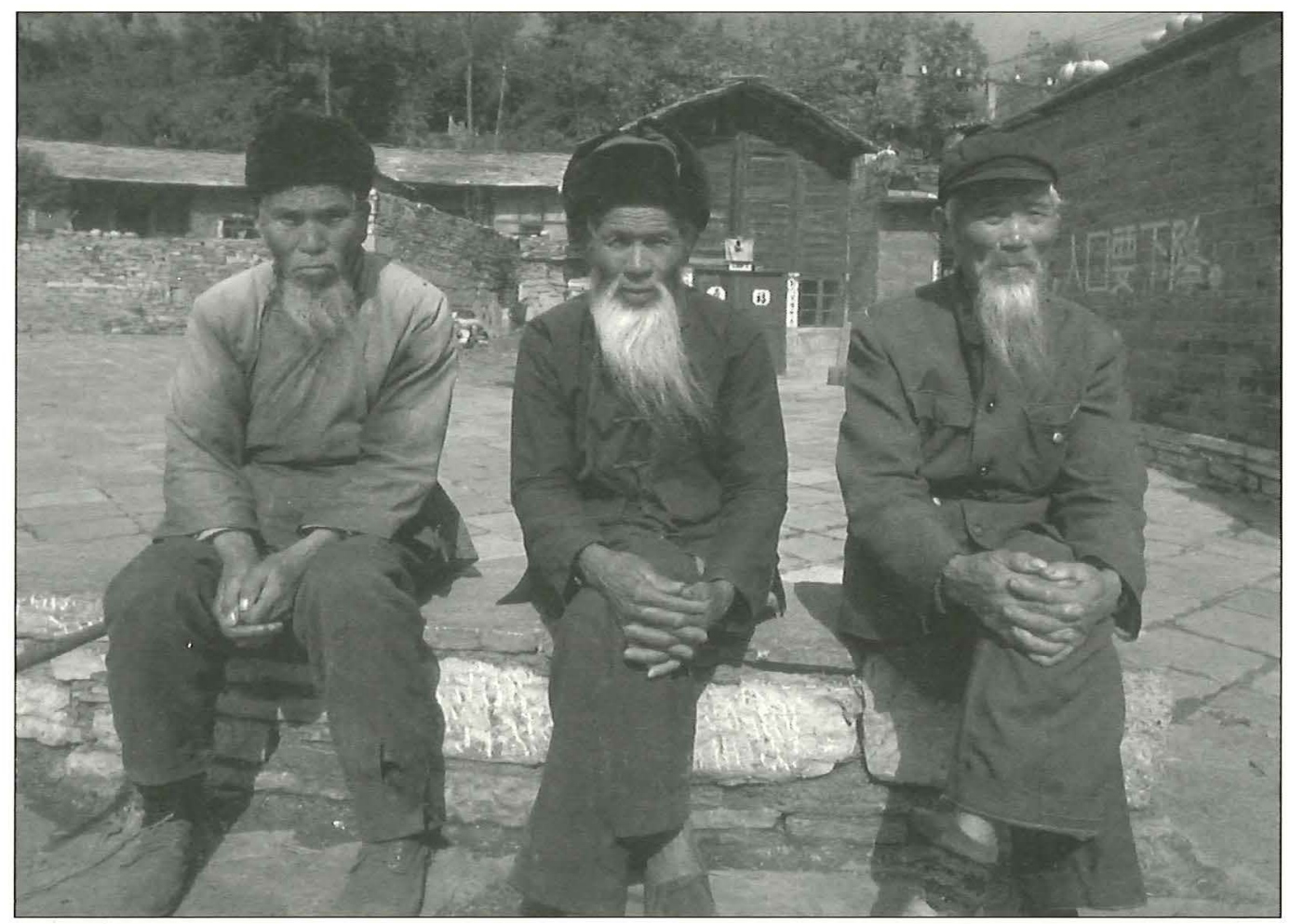

Left and above: From Zhenshan village in the Huaxi district of Guiyang city - a village populated mostly by the Buyi nationality. The second ecomuseum will be established here. Photo: John Aage Gjestrum.

in Jinping county; Tang'an Village in the Zhaoqing district of the Liping county. These three places all represent minority cultural heritages and different environmental situations. Zhenshan represents the Buyi nationality, Longli the Han culture in an area where Han people are a minority, Tang'an represents the Dong nationality.

\section{Zhenshan village}

in the Huaxi district of Guiyang city has 130 families and 560 inhabitants. The majority, 103 families, are of the Buyi nationality. The village is situated on Flower Lake and is surrounded by water on three sides. The whole area is ptotected as a nature reserve area.

The history of the village dates from 1600 when General Li Renyu was sent here on a mission by the Emperor. He married a Buyi girl with the family name of Ban. Their two sons, given the family names of Ban and Li, are the ancestors of the whole village population, which today represents the 17th generation since the general. Being a Buyi village, Zhenshan also has some memorials from the general 
84 of 400 years ago, e.g. the remains of the defensive wall surrounding the village, and the temple in celebration of General Li.

The economy is based on agriculture, with rice as the main product. The language spoken is Buyi. However, since the village is situated only $21 \mathrm{~km}$ south of the capital Guiyang, there is now a great deal of pressure on this minority culture.

In July 1995 the village became the first listed monument of its type at provincial level. Some support has been given by the government to help people preserve their houses. Being so close to the capital, the heritage authorities think this village may also be an example to other communities on how to handle conflicts between modernization and traditional culture. An eco- museum will be the right instrument in this situation. Planning for an ecomuseum documentation centre will start in 1999.

\section{Longli old town}

of the Jiping county is a Han Chinese town, with a structure unchanged since 1386, when Longli was founded as a military village. Because of its surroundings and very limited means of transportation, the town has been rather closed to the outside. In Jinping county about $70 \%$ of the 200,000 inhabitants belong to different minority nationalities. This actually makes the Han population in Longli old town a minority. This situation has caused the Han population to be very concerned about maintaining their traditional cultu-

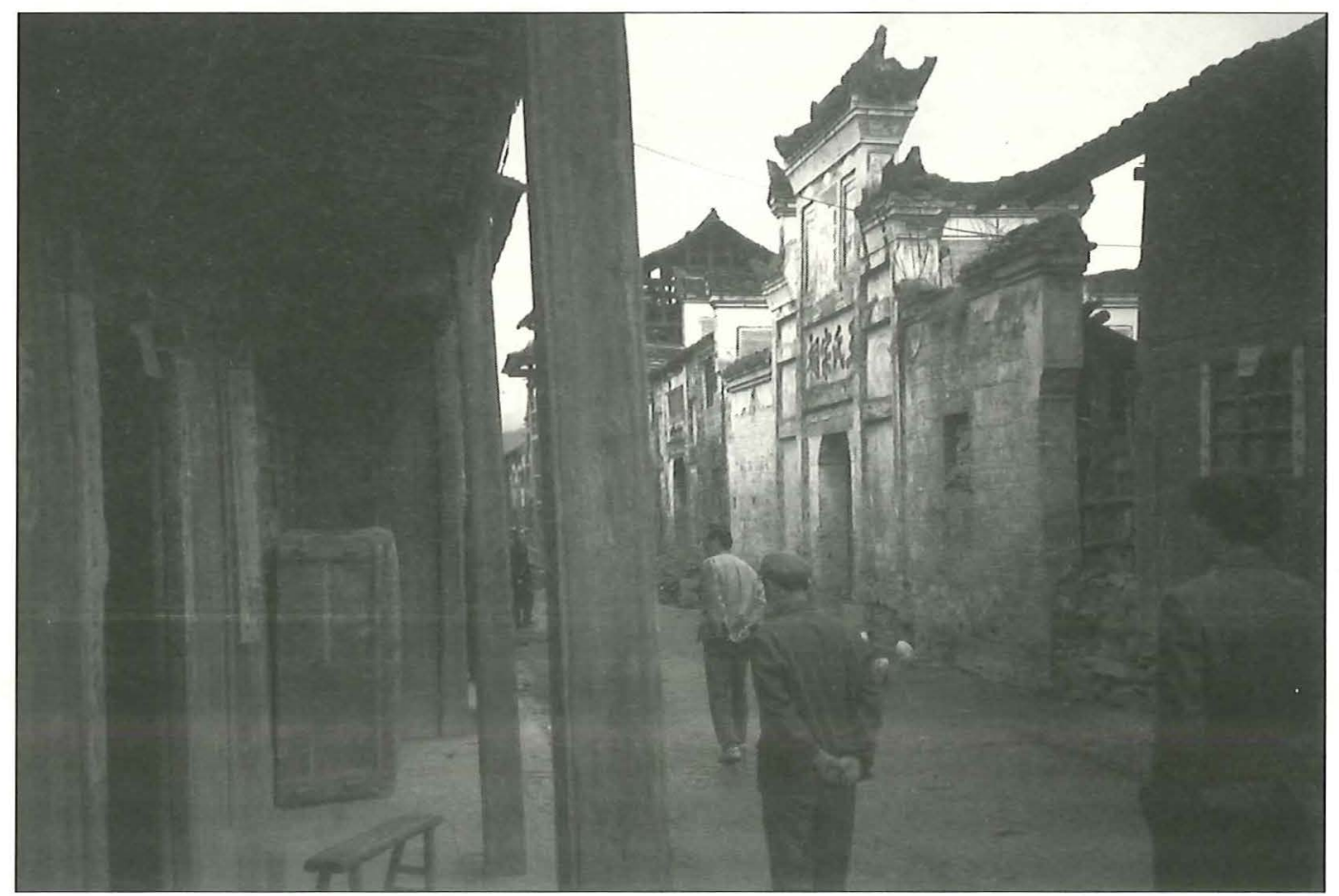




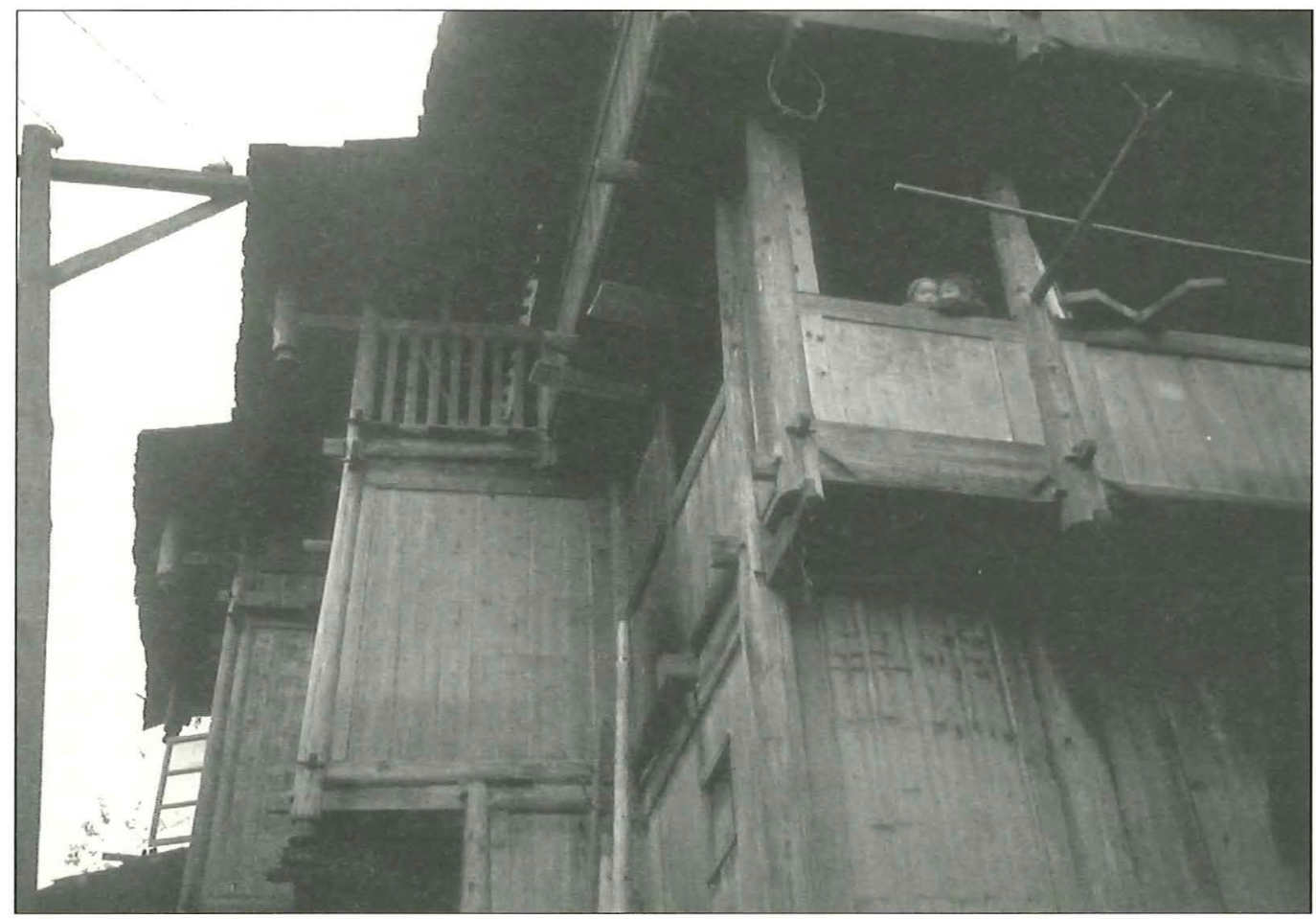

To the left: From Longli old town of the Jiping county, a Han Chinese town in a district where the Han is a minority. Above: Traditional Dong wooden houses in the Dong nationality village Tang'an in Liping county. The third and fourth ecomuseum will be established in Longli and Tang'an. Photo: John Aage Gjestrum.

re. The population in Longli township is about 6,000, and in the town itself 3,580 in 658 families.

The town is surrounded by ancient walls, with a drum tower in each corner. Preparations are being made to have this town listed as an historical town, representing a typical town structure from the Ming and Qing dynasties. There are several important monuments such as the town walls, temples, tombs and a famous old bridge. Together with all the old dwellings, this represents a lot of future challenges in making the town population understand and manage the preservation work needed. These tasks should be an important part of the work of an ecomuseum in the town.

\section{Tang'an village}

is situated in Liping county, $934 \mathrm{~m}$ above sea level. It is inhabited by 152 families of the Dong nationality, a total of 718 people. According to oral history, the oldest families came to the village because of wars during the period 1662-1723.

The village suffered from two big fires in 1950 and 1960. However, the houses 
86 were rebuilt in the traditional Dong style. An ecomuseum of the Dong people in this area would be a good instrument both in safeguarding the specific features of Dong culture, and as a way of presenting it to others.

\section{SOME POINTS OF DISCUSSION}

First, is there really any need for a museum in communities that can hardly produce what is necessary for their most basic survival? The answer to this question should be, yes.

When things are bad you really need more than ever to move them in the right direction. You need knowledge about the situation - and you need some self-confidence. In the case of the Soga and the Qing Miao group it is very clear that the attention given to the community by the outside world because of the ecomuseum, is something they have managed to transform into a general awareness of their situation and the qualities of their specific minority culture. Clearly their culture is at a point where there is a choice between survival or non-survival.

The educational role of the ecomuseum is also directed towards the population itself. The museum serves as a mirror in which the people can see their culture reflected. This makes them aware of the values of their culture and the responsibility they themselves have for its preservation.

Another point is that rather large numbers of the population are becoming directly involved in the work of the museum, - as craftsmen, as performers in the songs and dances for tourists, in documentation and arts and crafts projects. A museum in a small community is therefo- re very soon linked to the personal experiences of groups in the population. This will reduce the distance between museum and population.

The community leaders experience an increase in their importance and power. This implies an empowering of the group as a whole.

What about the future? Experiences in other countries show that the ecomuseums have a constantly changing life with different priority issues at different stages in the development of the museum. This will probably also be the case with Chinese ecomuseums. From the start such a museum is very often strongly linked to identity issues, community development in socially difficult situations, and later when some of the most urgent issues have been solved - it changes into something more like a traditional museum focussing on preservation and heritage issues. There is nothing wrong with such a development. A living culture is a changing culture. One tool in this process can be the ecomuseum, - even in China.

\section{An Laishun is academic secretary of the Chinese} Society of Museums and editor of the journal Chinese Museum. He is coordinator of the project Ecomuseums in Guizhou.

Adr. Chinese Society of Museums, 29. May 4th Street, Beijing 100009 China

Fax: +86-1065123119

email:anls@public.bta.net.cn

John Aage Gjestrum is the Norwegian editor of Nordisk Museologi. He is a researcher and museum consultant.

Adr. Kytdalen, N-2846 Norway

Fax: +47-61196013

email:johnaage@online.no 